DEPÓSITO LEGAL ZU2020000153

Esta publicación científica en formato digital

es continuidad de la revista impresa

ISSN 0041-8811

E-ISSN 2665-0428

Revista

de la

Universidad

del Tunlia

Fundada en 1947

por el Dr. Jesús Emrique Lossada

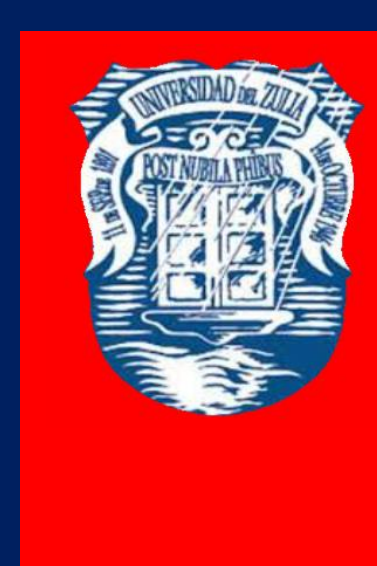

Ciencias

Sociales

y Arte

Aกัต 11 No 31

Septiembre - Diciembre 2021

Tercera ípoca

Maracailbo-Venezuela 


\title{
The mechanism of international cooperation accordingly to UN Convention against Transnational Organized Crime
}

\author{
Snizhana Romashkin * \\ Nadiia Shulzhenko ** \\ Kotova Liubov ***
}

\begin{abstract}
The article considers the mechanisms for fighting transnational crime and international cooperation in accordance with the United Nations Convention against Transnational Organized Crime and identifies the main factors that complicate international cooperation processes to combat transnational crime. The authors emphasize that international cooperation in the fight against crime is key to the success and guarantee of international security. The main objectives of the article are to carry out a comprehensive analysis of the concept of "organized crime" in accordance with the United Nations Convention against Transnational Organized Crime, to determine the corpus delicti, as well as to improve International Law to combat transnational crime. In the article the following methods are used: induction, deduction, analogy, as well as historical, dialectical, formal-legal methods. The article provides us with the complex results related to the key mechanisms of international cooperation according to the United Nations Convention against Transnational Organized Crime.

KEYWORDS: transnational crimes, criminal responsibility, international crimes, international conventions.
\end{abstract}

* PhD student of Academician Stashis Scientific Research Institute for the Study of Crime Problems, National Academy of Law Sciences of Ukraine, Kharkiv, Ukraine, http://orcid.org/0000-0002-2459-8727

* PhD, Assistant of the Department of Criminal Law, Yaroslav Mudryi National Law University, Kharkiv, Ukraine, http://orcid.org/0000-0002-9961-7574

*** PhD, Associate Professor of the Department of Law, Volodymyr Dahl East Ukrainian National University, Severodonetsk, Ukraine, http://orcid.org/0000-0002-2437-3624 


\section{El mecanismo de cooperación internacional de acuerdo con la Convención de la ONU contra la Delincuencia Organizada Transnacional}

RESUMEN

El artículo considera los mecanismos de lucha contra la delincuencia transnacional y la cooperación internacional de acuerdo con la Convención de las Naciones Unidas contra la Delincuencia Organizada Transnacional e identifica los principales factores que complican los procesos de cooperación internacional para combatir la delincuencia transnacional. Los autores enfatizan que la cooperación internacional en la lucha contra el crimen es clave en el éxito y garantía de la seguridad internacional. Los principales objetivos del artículo consisten en un análisis integral del concepto de "delincuencia organizada" de acuerdo con la Convención de las Naciones Unidas contra la Delincuencia Organizada Transnacional, para determinar el corpus delicti, así como mejorar el Derecho Internacional para combatir la delincuencia transnacional. En el artículo se utilizan los siguientes métodos: inducción, deducción, analogía, así como métodos históricos, dialécticos, formales-legales. El artículo nos proporciona los resultados complejos relacionados con los mecanismos clave de cooperación internacional de acuerdo con la Convención de las Naciones Unidas contra la Delincuencia Organizada Transnacional.

PALABRAS CLAVE: delitos transnacionales, responsabilidad penal, delitos internacionales, convenciones internacionales.

\section{Introduction}

One of the trends in modern transnational crimes is the desire of criminal structures to penetrate and succeed in the economy, politics, management, leadership of large companies and firms. In the process of fierce struggle for the right to control the profitable spheres of the economy and territory, the criminal environment is organized, the state apparatus is involved in its activities, it penetrates into the structures of power and management.

Ukraine is carrying out a legislation improvement, which is enshrined in the National Program for the Adaptation of Ukrainian Legislation to European Union Legislation. This adaptation also envisages a change in the Criminal Code in general and the parts related to organized transnational crime. Thus, transnational organized crime is committed by individuals in groups of at least three people, always aimed at committing crimes of medium gravity, serious 
REVISTA DE LA UNIVERSIDAD DEL ZULIA. 3a época. Año $11 \mathrm{~N}^{\circ}$ 31, 2020 Snizhana Romashkin et al. // The mechanism of international cooperation ...389-402

DOI: http://dx.doi.org/10.46925//rdluz.31.24

and especially serious in the territory of two or more states; these groups exist for a certain period of time; the main purpose of their activities is material or financial income; illegal acts committed by these groups are enshrined as crimes in the criminal law of the states in which they operate.

The main objectives of the Article are to conduct a comprehensive analysis of the concept of "organized crime" in accordance with the United Nations Convention against Transnational Organized Crime, to determine the corpus delicti, as well as to improve international law to combat transnational crime.

Transnational crime is now considered one of the most threatening factors, destroying the world economy, leading to poverty in the countries concerned and provoking other types of crime. Unfortunately, we can state that the world has not yet developed effective strategies to combat this phenomenon. Therefore, research on combating transnational economic crime should be continued, as their relevance only grows over time.

We believe that further research should be aimed at improving the international legal regulation of combating transnational crime.

\section{Theoretical framework}

A significant amount of scholars pay attention to the concept of transnational crimes and main problems of the international cooperation on combating this group of crimes. The works of the following scientists should be noted: Bilenchuk P.D, Kofanov A.V., Kobylyansky O.L., Paniotov E.K., Shulzhenko, N., Romashkin, S., Shulzhenko, O., Mokhonchuk, S, Dimitri Vlassis, Golina V. M. Kolodyzhnyi, Zharovska G.P, Vozniuk, A., Dudorov, O., Tytko, A., Movchan, R. Nevidoma, N.V., Zdorovko S.F., Popko V.V., Obokata, T., Shepetko S.A., Karpov N.S., Korolchuk V.V.

The authors Bilenchuk PD et al (2011), in their work "Transnational crime: forensic analysis" provide a complex analytic of the transnational crime's situation, determine key definitions and problems.

The authors Dimitri Vlassis (2002) in article "Overview of the Provisions of the United Nations Convention Against Transnational Organized Crime and Its Protocols" and Popko V.V. (2019)- "Criminalization of transnational acts in accordance with the UN Convention against 
REVISTA DE LA UNIVERSIDAD DEL ZULIA. 3a época. Año $11 \mathrm{~N}^{\circ}$ 31, 2020 Snizhana Romashkin et al. /// The mechanism of international cooperation ...389-402

DOI: http://dx.doi.org/10.46925//rdluz.31.24

Transnational Organized Crime 2000" - depict main aspects of the Convention 2000, with the detailed determination of the crimes 'elements.

Golina V. M. Kolodyzhnyi (2015), "World crime: modern tendencies and strategies of counteraction, Zharovska G.P. (2014) "International legal principles of combating transnational crime: problems and prospects." and Zdorovko S.F. (2014), "Application of generally accepted principles and norms of international law aimed at combating transnational crime." - provides us with the comparison regarding principles of the application of legal norms on combating transnational crimes.

The authors Shulzhenko, N., et al (2020) "Implementation of international crimes under the Rome Statute into national legal systems" indicate the main mechanisms for implementation Rome Statute into national legal systems and provide the determination of major international crimes accordingly to Rome Statute.

In the article "Implementation of UN and EU recommendations on criminalization of organized crimes" authors Vozniuk, A., et al (2020) presents comparative analysis of UN and EU recommendations to national legislators due to criminalization of international organized crimes.

The author Nevidoma, N.V. (2017) at her monograph "Committing a crime by an organized group" - analyze the definition of organized group and the forms on international cooperation as well as the comparison between elements on key crimes.

Obokata, T. (2017) "The Value of International Law in Combating Transnational Organized Crime in the Asia-Pacific", Shepetko S.A. (2013) "International experience in combating transnational organized crime. Fight against organized crime and corruption (theory and practice), Korolchuk V.V. (2013) "Current issues of prevention of transnational crime. Fight against organized crime and corruption (theory and practice), Novikova L.V. (2010), "Globalization and transnational economic crime: issues of the present" lead our attention to foreign methods and experience on combating transnational crimes in the period of globalization.

\section{Methodology}


REVISTA DE LA UNIVERSIDAD DEL ZULIA. 3a época. Año $11 \mathrm{~N}^{\circ}$ 31, 2020 Snizhana Romashkin et al. // The mechanism of international cooperation ...389-402

DOI: http://dx.doi.org/10.46925//rdluz.31.24

To achieve scientific objectivity of the research results, following general philosophical and special methods were used:

-historical method - to study the development of transnational crimes accordingly to UN Convention against Transnational Organized Crime and Additional Protocols and the international legal mechanism of cooperation between states in the fight against international crime in chronological order;

-dialectical system method - to determine the main directions of development of the international legal mechanism to combat transnational fragmentation accordingly to UN Convention against Transnational Organized Crime and Additional Protocols and National legal acts;

-formal-legal and comparative-legal - to analyze the provisions of international legal instruments and national legislation on combating transnational crime, namely Convention and Ukrainian Criminal and Criminal Procedure Code;

-statistical - to determine the level and rate of growth of transnational crime;

-modeling, multi-factoriality and forecasting - to develop recommendations for improving the international legal mechanism of cooperation between states in the fight against transnational crime.

\section{Results and discussions}

According to Art. 542 of the Criminal Procedure Code of Ukraine - international cooperation in criminal proceedings consists of the necessary measures which provide international legal assistance by documents transfer, performing certain procedural actions, criminals extraditions, transferring and continuing of criminal prosecution, criminal enforcements.

However, the international agreements, which are ratified by Ukraine, may also provide other forms of cooperation during criminal proceedings. Referring to paragraph 1 of Part 1 of Art. 541 of the Criminal Procedure Code of Ukraine, the international legal assistance is the conduct of the competent authorities of one state procedural actions, the implementation of which is necessary for pre-trial investigation, trial or for the execution of a sentence passed by a court of another state or international judicial institution (Zharovska, 2014). 
REVISTA DE LA UNIVERSIDAD DEL ZULIA. 3a época. Año $11 \mathrm{~N}^{\circ}$ 31, 2020 Snizhana Romashkin et al. /// The mechanism of international cooperation ...389-402

DOI: http://dx.doi.org/10.46925//rdluz.31.24

Discussing the general definition of organized crimes, we agree with the scientists Tkal O.V. and Sheludko A.A. and have to mention that there is no definition in the UN Convention against Transnational Organized Crime 2000, but there are indicated elements of a crime that is transnational in nature:

1. the crime is committed in two or more states;

2. the crime is committed on the territory of one state, but its preparation, planning, management is carried out in another state;

3. the crime is committed on the territory of one state, but with the participation of an organized criminal group, which carries out its activities on the territory of two or more states;

4. the crime is committed in the territory of one state, but the consequences of the offense occur in the territory of another state.

5. international instruments clearly define the concept of "organized crime".

Accordingly to International treaties the definition means the group activities of three or more persons, characterized by hierarchical connections or personal relationships that allow their leaders make a profit or control territories and markets, internal and external using the violence, intimidation or corruption, both for the purpose of continuing criminal activity and for the purpose of penetrating the legal economy (Tkal O. V., 2019).

What is more, transnational organized activity is determined by following conducts: illicit trafficking in narcotic drugs or psychotropic substances and money laundering, human trafficking, counterfeiting of banknotes, illegal trade in or theft of cultural objects, theft of nuclear material, mishandling or threat of mishandling in order to harm the population, terrorist acts, illicit trafficking in or theft of weapons or explosives or explosive devices, illegal trade in or theft of motor vehicles, bribery of government officials, etc.

The peculiarity is that each state prosecutes international crimes within its criminal jurisdiction. However, no countries in the world can face and successfully cope with the growth of international crime that is why the world community work on the International agreements in the direction of transnational crimes, one of such treaties is the UN Convention against Transnational Organized Crime and Additional Protocols. 
REVISTA DE LA UNIVERSIDAD DEL ZULIA. 3a época. Año $11 \mathrm{~N}^{\circ}$ 31, 2020 Snizhana Romashkin et al. // The mechanism of international cooperation ...389-402

DOI: http://dx.doi.org/10.46925//rdluz.31.24

Organized crime, which is initially perceived as a local or at least a regional threat, has already become a highly developed international activity. The level of crime either conducted by international criminal groups, or in the territory of several states, or against the interests of two or more countries has become completely high and dangerous, this type of crime became international or transnational.

More and more frequently numerous criminal groups operate at the international level, considering state borders not as barriers but as commercial opportunities (Golina, 2019). We totally agree with the professor Zdorovko, that today, no state, even a very economically developed, can effectively combat transnational crime without international cooperation (Zdorovko S. F., 2014).

The author V.V. Popko (2019) in his article indicates that domestic law contains similar rules for most transnational crimes in each country (terrorism, nuclear terrorism, bomb terrorism, hostage-taking, drug trafficking, human trafficking, corruption, money laundering, cybercrime, air piracy, piracy, ecocide, illegal manufacture and circulation of firearms, etc.). These transnational crimes have an international nature, but the prohibition of such crimes is defined in national law that's why we face the main difficulty of cooperation in combating such crimes (V.V. Popko, 2019)

Transnational crimes are extremely dangerous, guilty, harmful crimes for which severe penalties are provided accordingly to International law. However, there are differences in national legislation regarding their criminalization, definition of concepts, punishment, extradition, certain structural elements, which complicate the development of cooperation and interaction on international level (Nevidoma N.V., 2017).

As noted by M.I. Pashkovsky, the existence of foreign (international) element also entails certain complications in criminal procedure activities due to the institution of jurisdiction. That is, criminal procedural relations with a foreign (international) element can cause a conflict (conflict) as a jurisdictional (system of powers to criminalization, investigation, resolution of criminal cases and punishment persons guilty of crimes) and laws (criminal and criminal procedure) (Bilenchuk, 2011). 
REVISTA DE LA UNIVERSIDAD DEL ZULIA. 3a época. Año $11 \mathrm{~N}^{\circ}$ 31, 2020 Snizhana Romashkin et al. /// The mechanism of international cooperation ...389-402 DOI: http://dx.doi.org/10.46925//rdluz.31.24

Criminalization is one of the methods of application of criminal policy, and determines the basis of criminal law prohibitions, admissibility, possibility and expediency of recognizing a socially dangerous act as criminal and punishable. This process always relies on certain actions (inaction) to criminals, if they were not previously considered as such, with the definition of the crime and the possible punishment for its commission (Nevidoma, 2017).

Sometimes the term "criminalization" refers to the general strengthening of responsibility in the form of increased sanctions, the introduction of additional penalties and restrictions.

In the opinion of professor V.V. Popko (2019), criminalization is caused by: increasing the social danger of certain acts; the need to eliminate gaps in legislation; establishing new social relations that need protection through criminal law, and the most important criteria for criminalization are:

1) assessment of a person's behavior as socially dangerous;

2) recognition of behavior as contrary to morals and condemned by the majority of citizens;

3) a statement of the fact that the fight against such behavior is possible only through the application of criminal punishment and other coercive measures and that persuasion measures are not enough for this;

4) establishing the fact that the specified punishment is able to provide general and special prevention (V.V. Popko, 2019).

The concept of "transnational crime" has not convincing conceptual justification and unambiguous interpretation in jurisprudence: it is studied from different aspects and in different respects, but the most common approach is formulated in the UN Convention against Transnational Organized Crime in 2000 (Shostka O., 2009).

Transnational crime is an act committed by the subject of the crime with a "foreign or transnational element" (the act was committed in a foreign territory, there are foreign accomplices, etc.), which threatens important social relations, human life and health, security, freedom, nature, property, funds, etc.), or harms this relationship. The 2000 UN Convention provides a list of features that characterize the "foreign element" of a transnational crime (Article 3, paragraph 2) (Novikova L.V, 2010). 
REVISTA DE LA UNIVERSIDAD DEL ZULIA. 3e época. Año 11 N 31, 2020 Snizhana Romashkin et al. /// The mechanism of international cooperation ...389-402

DOI: $\underline{\text { http://dx.doi.org/10.46925//rdluz.31.24 }}$

The criminalization of transnational crimes includes numerous convention crimes and is based on international and regional conventions adopted by states with mandatory and/or strongly recommended standards for the criminalization of transnationally dangerous acts into domestic legislation.

International conventions cover those types of crime that are of particular concern to the international community, increase the capacity of States to cooperate in deterring such crimes, develop judicial assistance and establish the obligations of States to criminalize offenses, and outline their composition (Shostka O., 2009).

The list of transnational acts requiring criminalization in domestic law is provided for by the UN Convention against Transnational Organized Crime (2000) and two additional protocols thereto - against the smuggling of migrants by land, sea and air and on the prevention and cessation of trafficking in human beings, especially women and children.

It should be noted that the list of transnational crimes is not exhaustive, any crime with signs of transnationality requires criminalization in national law, according to Art. 2 of this Convention. There is also a provision that when the legislation of the participating States contains a list of specific major offenses, it includes at least "a comprehensive range of crimes related to the activities of organized criminal groups." According to the UN Convention of 2000 , criminalization requires:

a) participation in an organized criminal group, including involvement in a criminal group, as well as participation in a conspiracy (Article 5);

b) money laundering (Article 6);

c) the crime of corruption (Article 8);

d) obstruction of justice (Article 23).

The 2000 UN Convention stipulates that major offenses include crimes committed both within and outside the jurisdiction of the State party are concerned. Moreover, offenses committed outside any State jurisdiction shall constitute the principal offense only if the act is criminally punishable under the domestic law of the State in which it is committed and would be criminally punishable under the domestic law of the State Party. 
REVISTA DE LA UNIVERSIDAD DEL ZULIA. 3a época. Año $11 \mathrm{~N}^{\circ}$ 31, 2020 Snizhana Romashkin et al. // The mechanism of international cooperation ...389-402

DOI: http://dx.doi.org/10.46925//rdluz.31.24

Thus, the UN Convention against Transnational Organized Crime obliges States parties to criminalize transnational crimes that characterize the criminal activities of organized groups, first, participation in organized crime, money laundering, corruption, and obstruction of justice. Other anti-crime conventions oblige states to do the same for other transnational crimes (V.V. Popko, 2019).

The UN Convention against Transnational Organized Crime of 2000 conceptually covers the most paramount issues against transnational crimes including generalizing international legal treaty (Article 41), criminalization of certain types of crimes, jurisdiction of States Parties and liability of legal persons; harassment, court decisions and sanctions, confiscation and arrest, extradition, transfer of convicted persons, witness protection, mutual legal assistance of member states, joint investigations, transfer of criminal proceedings.

The crucial reason of the Convention is to encourage cooperation in the prevention and combating of transnational organized crime (Article 1).

Article 2 defines the terms "organized criminal group", "serious crime", "structured group", "property", "proceeds of crime", "arrest", "seizure", "confiscation", "principal offense", "Controlled supply" and "regional organization of economic integration". The concept of "serious crime" is not a clearly defined legal term, but paragraph b of this article clarifies that it is an act punishable by imprisonment for a maximum term and not less than four years or more severe punishment (V.V. Popko, 2019).)

The extradition law adopts a dual crime approach to this instrument of international assistance and cooperation. Extradition is the formal process of one state surrendering an individual to another state for prosecution or punishment for crimes committed in the requesting country's jurisdiction. Due to the national legislations - dual criminality is an obligatory requirement for extradition. A person who has been granted the refugee status, the status of a person in need of additional protection, or has been granted temporary protection in the State may not be extradited to the state, which refugee he/she is recognized, as well as to a foreign state, where his/her health, life or freedom is threatened based on race, confession, ethnicity, nationality, membership in a particular social group or political beliefs, except as provided for in the international treaty of the State. 
REVISTA DE LA UNIVERSIDAD DEL ZULIA. 3a época. Año $11 \mathrm{~N}^{\circ}$ 31, 2020 Snizhana Romashkin et al. /// The mechanism of international cooperation ...389-402

DOI: http://dx.doi.org/10.46925//rdluz.31.24

The issue of extradition in cases where a person is granted refugee status or political asylum in another country have to be examined separately.

The purpose of the Convention is to promote cooperation in the prevention and combating of transnational organized crime (Article 1).

The norms of the Convention stipulate the obligation of member states to take legislative and other measures in order to recognize as criminal penalties certain acts committed intentionally (Articles 7, 9) (Karpov N.S., 2004). The characteristics of criminalized acts are supplemented by measures aimed at establishing an internal regime of regulation and supervision and ensuring effective actions of state bodies (V.V. Popko, 2019).

One more specific point is indicated in the Convention is the obligation of the State parties to resolve all the problematic issues by consultation and dual assistance before they refuse an extradition request (Obokata, T. 2017). The main articles of the Convention on mutual legal assistance is much more extensive, having been called by some a "treaty within a treaty". In fact, the Convention outlines each element of mutual aid, even the conditions for rejection. It is necessary to remember that, although the document is primarily focused on comparable clauses in other treaties, it illustrates the significant development of the definition of reciprocal legal assistance as one of the key mechanisms for global development against criminal activity (Vlassis D.).

Article 11 (6) of the Convention enshrines the principle that the definition of crimes falls within the domestic law of each State Party. They may well be recognized in national law as criminal offenses that are somewhat different in scope (for example, two or more crimes under domestic law may constitute one crime covered by the Convention), especially when it reflects pre-existing law and case law. Thus, the provisions of the Convention and its protocols set only minimum standards that States must adhere to in the interests of coherence. States Parties may exceed these standards, as each State reserves the right not to be limited to them (Shepetko S.A., 2013).

Article 34 (3) provides that "each State Party may take more stringent or severe measures than those provided for in this Convention in order to prevent and combat transnational organized crime." Before using the wording or terms used in the Convention, national lawmakers 
REVISTA DE LA UNIVERSIDAD DEL ZULIA. 3a época. Año $11 \mathrm{~N}^{\circ}$ 31, 2020 Snizhana Romashkin et al. // The mechanism of international cooperation ...389-402

DOI: http://dx.doi.org/10.46925//rdluz.31.24

are encouraged to verify their compliance with the description of other crimes, the definitions and legal practices existing in the country. The Convention was developed for common purposes, as a result of which the level of abstraction of the Convention is higher than that required by domestic law.

Therefore, instead of literally incorporating certain provisions of the Convention into their legislation, the drafters of national laws are encouraged to convey their spirit and meaning (V.V. Popko, 2019).

States Parties are also urged to increase financial and technical aid to foreign countries in order to facilitate the effective application of the Convention. For the implementation of technical help to industrialized economies and growing economies, the Convention specifies that member states may seek to render sufficient and frequent financial contributions to a fund expressly allocated for this reason in the United Nations Funding system (Korolchuk V.V., 2013). After the identification and detention of a person whose extradition has been requested in his country of residence, the requested State shall immediately notify the State concerned, as well as the place and time of extradition.

\section{Conclusion}

To summarize, it must be mentioned that the modern criminal environment has a steady trend to improve criminal skills, internal organization, professionalism, technical equipment, etc. Important to ensure rights and legitimate interests of the individual, society and the state from criminal organized transnational crime is the development of countermeasures that would be adequate manifestations, forms and methods of criminal activity of these criminal groups.

The Convention is higher than is required by domestic law. In order to fulfill the obligations of Convention and protocols, many States need to enact new laws or amend them current legislation, as well as strengthen their law enforcement structures and criminal justice systems.

However, the Convention against Transnational Organized Crime, like other international law documents does not contain a single conceptual approach to the control and prevention of transnational national crime. This primarily applies to acts that infringe on the interests of 
REVISTA DE LA UNIVERSIDAD DEL ZULIA. 3a época. Año $11 \mathrm{~N}^{\circ}$ 31, 2020 Snizhana Romashkin et al. // The mechanism of international cooperation ...389-402

DOI: http://dx.doi.org/10.46925//rdluz.31.24

several states and In addition, they pose an international public danger (committed by individuals (groups of persons) outside the of any state, in order to achieve its own illegal goals). However, the adoption of a single document is necessary to develop an integrated approach and a single effective cooperation strategy in the field of combating serious forms of transnational organized crime. Consistent study of the problems of combating organized crime has led to the development of basic principles of interstate cooperation in the field of combating this phenomenon. Among the main can be distinguished pour: unification of the legal framework for combating transnational crime; counteracting funding organized crime; implementation of international law in the field of combating transnational organized crime into national law.

\section{References}

Assistance in Harmonising National Legislation with the United Nations Convention against Organized Crime and Protocol Thereto: Discussion Paper by the Secretariat, Working Group on Technical Assistance, CTOC/COP/WG.2/2013/4, at para. 6.

Bilenchuk PD, Kofanov AV, Kobylyansky OL, Paniotov E.K. (2011). Transnational crime: forensic analysis. -Monograph. Kyiv: KIY. 52 p.

Dimitri Vlassis (2002). Overview of the Provisions of the United Nations Convention Against Transnational Organized Crime and Its Protocols (From UNAFEI Annual Report for 2000 and Resource Material Series No. 59, P 452-474, Retrieved from: https:/www.unafei.or.jp/publications/pdf/RS No59/No59 32VE Vlassisl.pdf

Golina V. M. Kolodyzhnyi (2015). World crime: modern tendencies and strategies of counteraction. Bulletin of the National Academy of Legal Sciences of Ukraine. 2015. № 2. p. 92 100. - Retrieved from: http://nbuv.gov.ua/UJRN/vapny 2015212

Implementation of the United Nations Convention against Transnational Organized Crime: Needs Assessment Tools, 2016, UNTOC. Retrived from: https://www.heuni.fi/material/attachments/heuni/uusikansio/eBuA7jG9v/UNTOC_need_asses sment_tool.pdf

Karpov N.S. (2004). Criminal activity: Monograph. - Kyiv: Serhiy Semenko Publishing House. $310 \mathrm{p}$

Korolchuk V.V. (2013). Current issues of prevention of transnational crime. Fight against organized crime and corruption (theory and practice). № 1. p. 217-226. Retrieved from: http://nbuv.gov.ua/UJRN/boz_2013_1_26 
REVISTA DE LA UNIVERSIDAD DEL ZULIA. 3a época. Año 11 N 31, 2020 Snizhana Romashkin et al. // The mechanism of international cooperation ...389-402

DOI: http://dx.doi.org/10.46925//rdluz.31.24

Nevidoma, N.V. (2017). Committing a crime by an organized group: monograph. Yaroslav Mudryi National Law University. Kharkiv: Pravo, 222 p.

Novikova L.V. (2010). Globalization and transnational economic crime: issues of the present. Law and Security. № 3. P. 26-30. - Retrieved from: http://nbuv.gov.ua/UJRN/Pib_2010_3_7

Obokata, T. (2017). The Value of International Law in Combating Transnational Organized Crime in the Asia-Pacific. Asian Journal of International Law, 7(1), 39-60. doi:10.1017/S2044251315000193

Popko V.V. (2019). Criminalization of transnational acts in accordance with the UN Convention against Transnational Organized Crime 2000. Nat. University of Bioresources and Nature Management of Ukraine. Kyiv. Vol. 10, № 3. p. 151-158.

Shepetko S.A. (2013). International experience in combating transnational organized crime. Fight against organized crime and corruption (theory and practice). № 1. p. 298-306. Retrieved from: http://nbuv.gov.ua/UJRN/boz 2013136

Shostka O. (2009). Combating organized crime in Europe: monograph : Pravo, - 400 p.

Shulzhenko, N., Romashkin, S., Shulzhenko, O., \& Mokhonchuk, S. (2020). Implementation of international crimes under the Rome Statute into national legal systems. Amazonia Investiga, 9(28), 528-535. https://doi.org/10.34069/AI/2020.28.04.57

United Nations Office of Drugs and Crime (UNODC), Transnational Organized Crime in East Asia and the Pacific: A Threat Assessment (Vienna: UNODC, 2013) at Executive Summary

Verbensky M.G., (2010). Transnational crime: criminological characteristics and ways of prevention: dissertation. Dnepropetrovsk. 503 p

Vozniuk, A., Dudorov, O., Tytko, A., \& Movchan, R. (2020). Implementation of UN and EU recommendations on criminalization of organized crimes. Amazonia Investiga, 9(28), 234-240. https://doi.org/10.34069/AI/2020.28.04.26

Zdorovko S.F. (2014). Application of generally accepted principles and norms of international law aimed at combating transnational crime. Bulletin of Karazin Kharkiv National University. Series: International Relations. Economy. Local. Tourism. № 1144, issue. 4 (2). p. 15-21. Retrieved from: http://nbuv.gov.ua/UJRN/VKhMv $2014 \quad 1144 \quad 4 \% 282 \% 29 \quad 5$

Zharovska G.P. (2014). International legal principles of combating transnational crime: problems and prospects. Almanac of International Law. Edition 6. p. 90-100. Retrieved from: http://nbuv.gov.ua/UJRN/amp 2014613 